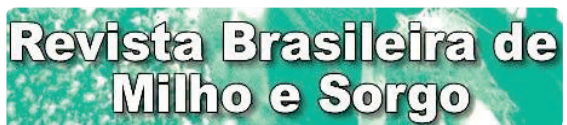

Brazilian Journal of Maize and Sorghum

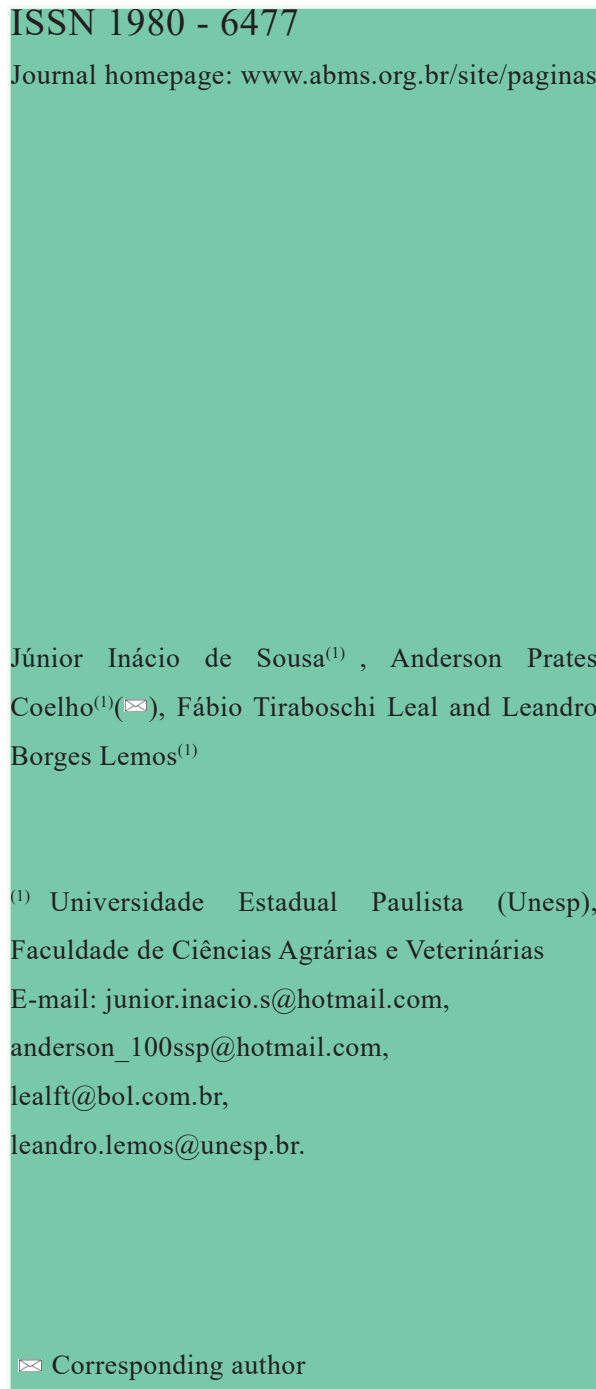

How to cite

SOUSA, J. I.; COELHO, A. P.; LEAL, F. T. LEMOS, L. B. Top-dressing nitrogen doses in maize sown in single and double rows and cultivated in winter. Revista Brasileira de Milho e Sorgo, v. 19, e1211, 2020.

\section{TOP-DRESSING NITROGEN DOSES IN MAIZE SOWN IN SINGLE AND DOUBLE ROWS AND CULTIVATED IN WINTER}

\begin{abstract}
Due to the intensification of production in irrigated areas, maize has been sown in winter, enabling three seasons in one agricultural year. The objective of this study was to evaluate the agronomic performance of maize under irrigation and cultivated in winter under different plant arrangements (single and doublerow) under top-dressing nitrogen doses. The experimental design used was in randomized blocks in a split-plot scheme, with four replicates. Plots were formed by sowing systems single and double rows and subplots were formed by four top-dressing $\mathrm{N}$ doses: $0 \mathrm{~kg} \mathrm{ha}^{-1}$ of $\mathrm{N} ; 80 \mathrm{~kg} \mathrm{ha}^{-1}$ of $\mathrm{N}$ with single application in phenological stage $\mathrm{V}_{3} ; 160 \mathrm{~kg} \mathrm{ha}^{-1}$ of $\mathrm{N}$ with application of $80 \mathrm{~kg} \mathrm{ha}^{-1}$ in $\mathrm{V}_{3}$ and $\mathrm{V}_{6}$, and $240 \mathrm{~kg} \mathrm{ha}^{-1}$ of $\mathrm{N}$ with application of $80 \mathrm{~kg} \mathrm{ha}^{-1}$ in stages $\mathrm{V}_{3}, \mathrm{~V}_{6}$ and $\mathrm{V}_{8}$. The single-row sowing system led to higher grain yield compared to maize grown in the double-row system. Maize grain yield showed progressive linear increments with increasing top-dressing $\mathrm{N}$ doses, reaching $11,089 \mathrm{~kg} \mathrm{ha}^{-1}$ of grains with the maximum studied dose of $240 \mathrm{~kg} \mathrm{ha}^{-1}$ of $\mathrm{N}$. Sowing systems in single and double rows do not differ with respect to the use of top-dressing $\mathrm{N}$.
\end{abstract}

Keywords: Zea mays L., spatial arrangement, twin rows, nitrogen fertilizer, grain yield.

\section{DOSES DE NITROGÊNIO EM COBERTURA NO MILHO SEMEADO EM LINHAS SIMPLES E DUPLAS E CULTIVADO NO INVERNO}

\begin{abstract}
Resumo - Devido à intensificação de produção em áreas irrigadas, o milho tem sido semeado no inverno, possibilitando três safras em um ano agrícola. Objetivouse avaliar o desempenho agronômico do milho irrigado e cultivado no inverno sob diferentes arranjamentos de plantas (linhas simples e duplas) sob doses de nitrogênio em cobertura. $\mathrm{O}$ delineamento experimental utilizado foi em blocos casualizados em esquema de parcelas subdivididas, com quatro repetições. As parcelas foram formadas pelos sistemas de semeadura linhas simples e duplas e as subparcelas formadas por quatro doses de nitrogênio em cobertura: $0 \mathrm{~kg} \mathrm{ha}^{-1} \mathrm{de}$ $\mathrm{N} ; 80 \mathrm{~kg}^{-1}$ de $\mathrm{N}$ com aplicação única no estádio fenológico $\mathrm{V}_{3} ; 160 \mathrm{~kg} \mathrm{ha}^{-1} \mathrm{de} \mathrm{N}$ com aplicação de $80 \mathrm{~kg} \mathrm{ha}^{-1}$ de $\mathrm{N}$ em $\mathrm{V}_{3}$ e $\mathrm{V}_{6}$ e $240 \mathrm{~kg} \mathrm{ha}^{-1}$ de $\mathrm{N}$ com aplicação de $80 \mathrm{~kg} \mathrm{ha}^{-1}$ nos estádios $\mathrm{V}_{3}, \mathrm{~V}_{6}$ e $\mathrm{V}_{8}$. O sistema de semeadura em linhas simples apresentou produtividade de grãos maior do que o milho cultivado no sistema em linhas duplas. A produtividade de grãos do milho apresentou incrementos lineares crescentes com o aumento das doses de $\mathrm{N}$ em cobertura, obtendo-se $11.089 \mathrm{~kg}$ $\mathrm{ha}^{-1}$ de grãos com a dose máxima estudada de $240 \mathrm{~kg} \mathrm{ha}^{-1}$ de $\mathrm{N}$. Os sistemas de semeadura em fileiras simples e duplas não diferem entre si quanto ao uso do $\mathrm{N}$ em cobertura.
\end{abstract}

Palavras-chave: Zea mays L., arranjo espacial, linhas gêmeas, fertilizante nitrogenado, produtividade de grãos. 
Maize is the most consumed cereal in the world, being grown in more than 150 countries in a total area of more than 230 million hectares (FAO, 2020). The average crop yield in Brazil is $5.7 \mathrm{t} \mathrm{ha}^{-1}$ (CONAB, 2020), a value considered low, since the yield in countries such as the United States is close to $12 \mathrm{t} \mathrm{ha}^{-1}$ (FAO, 2020). In irrigated areas, however, maize yield in Brazil is high, with values of up to $15 \mathrm{t} \mathrm{ha}^{-1}$ (Ben et al., 2016). Therefore, specific agricultural managements should be adopted to increase the yield of this cereal in the country.

In Brazil, maize is usually grown in two seasons. The first season comprises sowing from October to December, while in the second season sowing is performed between January and March. Thus, most studies with maize crop focus on these two seasons. More recently, maize sowing began to be performed in a third season, in irrigated areas with high level of technology and land use intensification. The maize sowing in the third season is only possible in regions with milder winters, with higher minimum temperatures, as in most of the Brazilian Cerrado, being one of the main Brazilian regions with the third-season maize crop under irrigated conditions. The sowing of third-season maize is carried out in winter, between June and August (CONAB, 2020).

Due to the intensification of this production system, super-early maize cultivars are generally used, and harvest is performed within 130 days after sowing (Crusciol et al., 2010). However, studies indicate that maize cultivars with shorter cycles have lower production potential than medium- and late-cycle cultivars (Crusciol et al., 2013). In this context, the evaluation of systems that can increase the yield of super-early cultivars is essential to increase the revenue obtained by the producer.

Among the managements that can be studied to maximize the yield of maize under irrigation and cultivated in winter, the sowing system and the management of top-dressing nitrogen $(\mathrm{N})$ fertilization can be highlighted $(\mathrm{Xu}$ et al., 2020). The response to $\mathrm{N}$ fertilization is due to the high demand for this nutrient in maize crop, because it is the most extracted and most exported macronutrient (Fornasieri Filho, 2007; Xu et al., 2020).

It is verified that the recommendation of top-dressing $\mathrm{N}$ for maize does not take into account the cultivation system, and the maximum recommended $\mathrm{N}$ dose is $140 \mathrm{~kg} \mathrm{ha}^{-1}$ for the State of São Paulo (Raij et al., 1996). However, for low-response classes, in areas with high intensification and crop rotation with legumes, such as in irrigated areas, the maximum recommended dose of top-dressing $\mathrm{N}$ is $70 \mathrm{~kg}$ $\mathrm{ha}^{-1}$. For irrigated areas, where up to three seasons are conducted in one agricultural year, studies are needed for an adequate recommendation of top-dressing $\mathrm{N}$ fertilization in maize.

Management of the spatial arrangement of maize plants can contribute to the increase in crop yield (Carvalho et al., 2020a). Studies indicate that maize sowing in double rows, or twin rows, increase yield compared to sowing in single rows 
(Bettio et al., 2017; Jones, 2010). However, the increase in maize yield due to sowing in double rows is contradictory (Robles et al., 2012; Novacek et al., 2013), so further studies focusing on this topic need to be conducted. The double rows system in maize is characterized by sowing with spacing between rows alternating, such as $0.45 \times 0.90 \mathrm{~m}$ and $0.50 \times 1.00 \mathrm{~m}$, in which there are rows closer and more distant, similar to what occurs with pineapple and sugarcane crops.

The hypotheses of this study are (a) there are differences in the agronomic performance of maize between the sowing systems of single and double rows, (b) maize cultivation in winter under irrigation increases grain yield with the application of increasing $\mathrm{N}$ doses and (c) the single-row and double-row sowing systems differ in terms of the management of top-dressing $\mathrm{N}$ fertilization. Therefore, the objective of this study was to evaluate the agronomic performance of maize under irrigation and cultivated in winter under different plant arrangements (single-row and double-row) under top-dressing $\mathrm{N}$ doses.

\section{Material and Methods}

The experiment was conducted in the municipality of Guaíra, São Paulo, in an area located near the coordinates $20^{\circ} 22^{\prime} 20^{\prime \prime} \mathrm{S}$ latitude and $48^{\circ} 22^{\prime} 10^{\prime}$ 'W longitude, at altitude of $500 \mathrm{~m}$. According to Köppen's classification, the climate of the region is Aw, humid tropical with rainy season in summer and dry season in winter, with an average annual precipitation of
1,400 mm (Alvares et al., 2013).

Twenty days prior to maize sowing (July 06, 2018), a composite soil sample was collected in the $0.00-0.20 \mathrm{~m}$ layer for fertility analysis. The results were: $\mathrm{OM}=26 \mathrm{~g} \mathrm{dm}^{-3} ; \mathrm{pH}\left(\mathrm{CaCl}_{2}\right)=4.9$; $\mathrm{P}($ resin $)=31 \mathrm{mg} \mathrm{dm}^{-3} ; \mathrm{K}^{+}=3.2 \mathrm{mmol}_{\mathrm{c}} \mathrm{dm}^{-3} ; \mathrm{Ca}^{2+}$ $=34 \mathrm{mmol}_{\mathrm{c}} \mathrm{dm}^{-3} ; \mathrm{Mg}^{2+}=12 \mathrm{mmol}_{\mathrm{c}} \mathrm{dm}^{-3} ; \mathrm{H}+\mathrm{Al}=$ $29 \mathrm{mmol}_{\mathrm{c}} \mathrm{dm}^{-3} ; \mathrm{CEC}=78 \mathrm{mmol}_{\mathrm{c}} \mathrm{dm}^{-3} ; \mathrm{V}=63 \%$; $\mathrm{S}=12 \mathrm{mg} \mathrm{dm}^{-3} ; \mathrm{B}=0.25 \mathrm{mg} \mathrm{dm}^{-3} ; \mathrm{Cu}=1.9 \mathrm{mg}$ $\mathrm{dm}^{-3} ; \mathrm{Fe}=29 \mathrm{mg} \mathrm{dm}^{-3} ; \mathrm{Mn}=14.3 \mathrm{mg} \mathrm{dm}^{-3}$ and $\mathrm{Zn}=2.7 \mathrm{mg} \mathrm{dm}^{-3}$. The soil of the area is classified as Latossolo Vermelho Eutroférrico (Oxisol) of clayey texture (Santos et al., 2018). The soil has $120 \mathrm{~g} \mathrm{~kg}^{-1}$ of sand, $290 \mathrm{~g} \mathrm{~kg}^{-1}$ of silt and $590 \mathrm{~g} \mathrm{~kg}^{-1}$ of clay. Soil acidity was not corrected to install the experiment. Soil acidity was not corrected to install the experiment.

The experiment was carried out in an area irrigated by center pivot, under no-tillage management, and the crop was referred to as winter maize, or third-season maize. Prior to the sowing of the experiment, in the agricultural years 2015/2016, 2016/2017 and 2017/2018 the pivot area was cultivated with: soybean, common bean and maize; soybean and tomato; soybean and common beans, respectively. The common bean grown in the experimental area, harvested on July 26, 2018, had an average yield of 2,727 $\mathrm{kg} \mathrm{ha}^{-1}$, and maize was sown on the same day.

The experimental design used was randomized blocks in a split-plot scheme, with four replicates. The plots were formed by two sowing systems (single rows and double rows) and the subplots were formed by four doses of 
top-dressing $\mathrm{N}\left(0,80,160\right.$ and $240 \mathrm{~kg} \mathrm{ha}^{-1}$ of $\left.\mathrm{N}\right)$. The $\mathrm{N}$ dose of $80 \mathrm{~kg} \mathrm{ha}^{-1}$ was applied at once, when maize was in the phenological stage $\mathrm{V}_{3}$, the dose of $160 \mathrm{~kg} \mathrm{ha}^{-1}$ was split into two portions of $80 \mathrm{~kg} \mathrm{ha}^{-1}$ each, the first in $\mathrm{V}_{3}$ and the second in $\mathrm{V}_{6}$, and the dose of $240 \mathrm{~kg} \mathrm{ha}^{-1}$ was split into three portions of $80 \mathrm{~kg} \mathrm{ha}^{-1}$ each, the first applied in $\mathrm{V}_{3}$, the second in $\mathrm{V}_{6}$ and the third in $\mathrm{V}_{8}$. It was decided not to exceed $80 \mathrm{~kg} \mathrm{ha}^{-1}$ of $\mathrm{N}$ in each application of the nutrient, according to Raij et al. (1996). Top-dressing $\mathrm{N}$ fertilization was performed using the fertilizer FH Nitro Mais ${ }^{\circledR}$, whose formulation is defined as $43-00-00+0.15 \% \mathrm{Cu}+0.4 \% \mathrm{~B}$. The experimental plots were delimited with $12 \mathrm{~m}$ length and $8 \mathrm{~m}$ width, with a total of 32 plots $(8$ treatments $\mathrm{x} 4$ replicates). For the evaluations, $1 \mathrm{~m}$ was disregarded on each side of the plots.

The maize hybrid used was AG9000PRO3, and the seeds were industrially treated with the insecticide Clothianidin (2.1 g a.i. $\mathrm{kg}^{-1}$ of seeds) and the fungicide Fludioxonil $\left(0.4 \mathrm{~g}\right.$ a.i. $\mathrm{kg}^{-1}$ of seeds). This hybrid has relative maturity of 130 days, flowering (average) of 53 days, defined as super-early, with plant height of $229 \mathrm{~cm}$, ear insertion height of $113 \mathrm{~cm}$, erect leaf architecture, yellow and semi-dent grains, number of rows between 16 and 18, and 1000-grain weight (average) of $328 \mathrm{~g}$. In addition, this hybrid has the VT PRO3 technology, which assists in the protection against caterpillars and tolerance to glyphosate and with high response to the increase in plant population ha ${ }^{-1}$ and to the increase in topdressing N doses (Sementes Agroceres, 2020).

Maize was sown using a New Holland PL
$5000 \circledR$ seeder, with GPS and digital adjustment system for distribution of seeds and fertilizers. The whole area was fertilized according to the chemical characteristics of the soil and recommendations proposed by Raij et al. (1996), with an expected yield of $10 \mathrm{tha}^{-1}$. Thus, $24 \mathrm{~kg}$ ha $^{-1}$ of N, $84 \mathrm{~kg} \mathrm{ha}^{-1}$ of $\mathrm{P}_{2} \mathrm{O}_{5}$ and $48 \mathrm{~kg} \mathrm{ha}^{-1}$ of $\mathrm{K}_{2} \mathrm{O}$ were distributed, applying $300 \mathrm{~kg} \mathrm{ha}^{-1}$ of the 08 28-16 formulation.

The seed population used in the sowing of the experiment, for all treatments, was 60,000 seeds $\mathrm{ha}^{-1}$. For the single-row cultivation system, the spacing between rows was $0.50 \mathrm{~m}$. For the double-row cultivation system, two rows were sown with spacing of $0.50 \mathrm{~m}$ and interval of 1.00 $\mathrm{m}$, which resulted in an average spacing between rows of $0.75 \mathrm{~m}$. Were used 4.5 seeds per meter in the double-row sowing system and 3.0 seeds per meter in the single-row sowing system.

Pest control was carried out using insecticides with the active ingredient lambdacyhalothrin (62.5 $\mathrm{g} \mathrm{ha}^{-1}$ of a.i.), applied in phenological stage $\mathrm{V}_{3}$, and imidacloprid $(168 \mathrm{~g}$ ha $^{-1}$ of a.i.), beta-cyfluthrin ( $12.5 \mathrm{~g} \mathrm{ha}^{-1}$ of a.i.) plus spinetoram (12 $\mathrm{g} \mathrm{ha}^{-1}$ a.i.), applied in $\mathrm{V}_{5}$. Weeds were controlled using the herbicides glyphosate (1,780 $\mathrm{g} \mathrm{ha}^{-1}$ a.i.) and atrazine (1,000 $\mathrm{g} \mathrm{ha}^{-1}$ a.i.), applied in $\mathrm{V}_{5}$. For the control of fungal diseases, the fungicides pyraclostrobin (99.75 $\mathrm{g} \mathrm{ha}^{-1}$ of a.i.) and epoxiconazole (37.5 $\mathrm{g} \mathrm{ha}^{-1}$ of a.i.) were applied in $\mathrm{V}_{12}$.

Irrigation was performed according to the water demand of maize crop, as recommended by Allen et al. (1998). The irrigation depth 
accumulated during the experimental period was $280 \mathrm{~mm}$. Irrigation management was carried out via climate, with data obtained from the meteorological station located $600 \mathrm{~m}$ from the experiment, using the reference evapotranspiration and crop coefficients (Kc) obtained according to Allen et al. (1998). The period between irrigates used was 4 days, that is, the applied irrigation depth supplied the sum of the maize evapotranspiration, discounting precipitation, in this period. The average maximum and minimum temperatures during the experimental period were 31.3 and 19.3 ${ }^{\circ} \mathrm{C}$, respectively, with accumulated precipitation of $534.5 \mathrm{~mm}$ (Figure 1).

Chlorophyll index was measured at 64 days after sowing, female flowering phase $\left(\mathrm{R}_{1}\right)$. The lower leaves opposite to the ear insertion were collected, 4 leaves per subplot. In the middle third of each leaf, the chlorophyll index was read with the device CCM-200 "Chlorophyll Content Meter - Opti-Sciences ${ }^{\circledR}$ ". The readings were performed between 9:00 a.m. and 10:00 a.m. In these same leaves, leaf $\mathrm{N}$ content was determined by following the method described by Malavolta et al. (1997).

After 131 days of sowing, the experiment was harvested and, on the same day, the following parameters were evaluated: plant height, ear height, stem diameter, plant population, number of rows per ear, number of grains per row and grain yield. For plant height, 4 plants were measured per subplot, from the first internode to the end of the spike. Ear height was measured from the first internode to the base of the ear. Stem diameter was measured at the second internode in 4 plants per subplot, with a caliper. To evaluate plant population, the number of plants was counted in 6 meters of maize row, in 4 central rows of the subplot, and the number of plants per hectare was estimated as a function of each spacing used. The variables number of rows per ear and number of grains per row were quantified by counting four ears per subplot, in four plants in a row. 1000-grain weight $(\mathrm{g})$ was obtained by randomly collecting four samples of 1000 grains, weighing them and correcting the values to $0.13 \mathrm{~kg} \mathrm{~kg}^{-1}$ on a wet basis. Grain yield ( $\mathrm{kg}$ $\mathrm{ha}^{-1}$ ) was obtained by manually harvesting maize ears in 6 meters of each usable row, in 4 central rows of the subplot, and then the ears were mechanically threshed, determining grain yield per hectare and correcting to $0.13 \mathrm{~kg} \mathrm{~kg}^{-1}$ on a wet basis.

At the time of maize harvest, samples were collected from the shoots of 4 consecutive plants in one of the usable rows of the subplot, and then separated into two subsamples: grains and straw (stem, leaves, tassel and cob) for subsequent calculation of the efficiencies in $\mathrm{N}$ use by the crop: agronomic efficiency (AE), physiological efficiency (PE), agrophysiological efficiency (APE), recovery efficiency (RE) and utilization efficiency (UE). The samples were placed in paper bags, taken to the laboratory for drying in an oven with forced air circulation at $60-65^{\circ} \mathrm{C}$ until constant weight and were subsequently ground in a Wiley mill. The $\mathrm{N}$ contents in grain and straw were determined according to the method described 


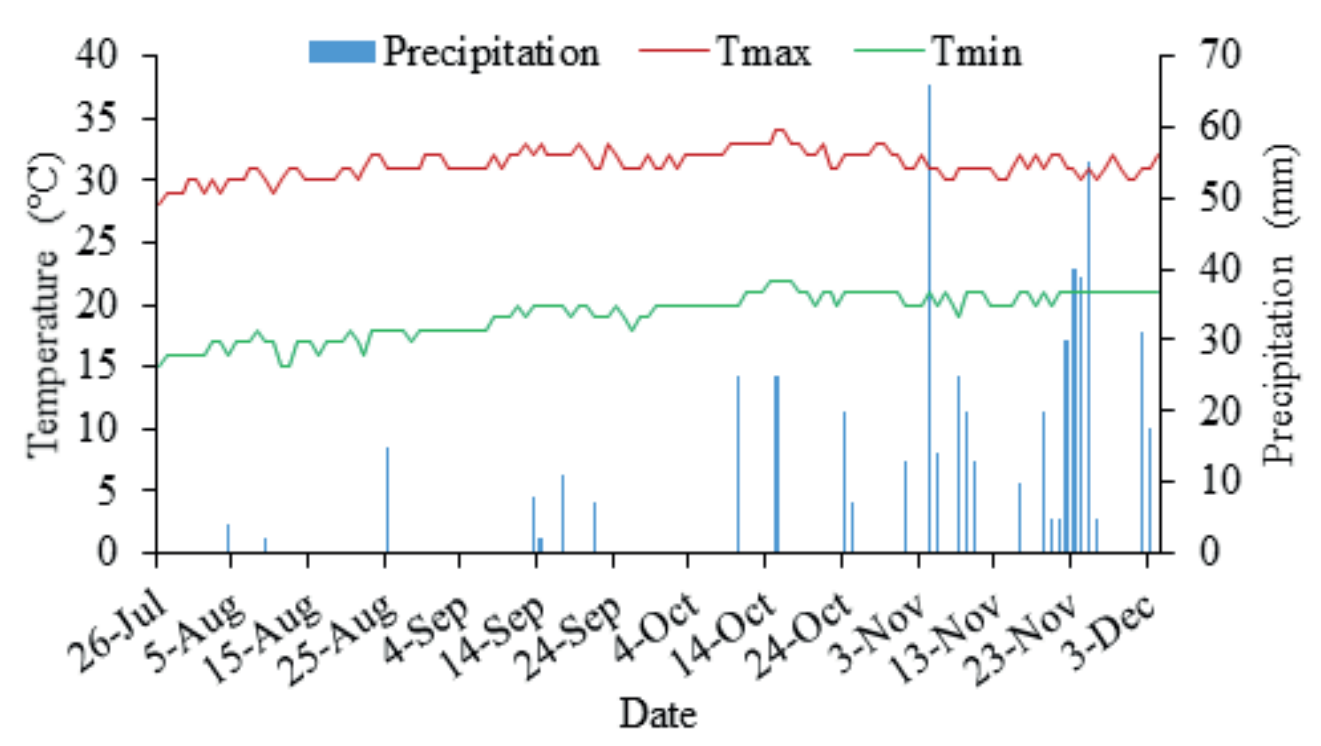

Figure 1. Precipitation and maximum and minimum daily temperatures during the experiment. Sowing on July 26 and harvest on December 4. Source: Weather Station of Bom Sucesso Farm of Tereos Mill - Guaíra, SP (located $600 \mathrm{~m}$ from the experiment).

by Malavolta et al. (1997). The $\mathrm{N}$ accumulation in each subsample was calculated by multiplying the $\mathrm{N}$ content by the dry mass of each part.

Agronomic efficiency was calculated using the equation: $\mathrm{AE}=(\mathrm{GYwf}-\mathrm{GYwof}) /(\mathrm{QNa})$, expressed in $\mathrm{kg} \mathrm{kg}^{-1}$, where $\mathrm{GYwf}=$ grain yield with fertilizer; GYwof = grain yield without fertilizer; and $\mathrm{QNa}=$ quantity of $\mathrm{N}$ applied in $\mathrm{kg}$ $\mathrm{ha}^{-1}$. Physiological efficiency was calculated using the equation: $\mathrm{PE}=(\mathrm{TBPwf}-\mathrm{TBPwof}) /(\mathrm{ANwf}$ - ANwof), expressed in $\mathrm{kg} \mathrm{kg}^{-1}$, where TBPwf = total biological production (shoot dry mass) with fertilizer; TBPwof $=$ total biological production without fertilizer; ANwf = accumulation of the nutrient in the shoots with fertilizer; and ANwof $=$ accumulation of the nutrient in the shoots without fertilizer. Agro-physiological efficiency was calculated using the equation: $\mathrm{APE}=(\mathrm{GYwf}$ - GYwof) / (ANwf - ANwof), expressed in kg $\mathrm{kg}^{-1}$, where GYwf = grain yield with fertilizer; GYwof = grain yield without fertilizer; ANwf = accumulation of the nutrient in the shoots with fertilizer and ANwof = accumulation of the nutrient in the shoots without fertilizer. Recovery efficiency was calculated using the following equation: RE = ((ANwf - ANwof / QNa) $) \times 100$, expressed in \%, where ANwf = accumulation of the nutrient in the shoots with fertilizer and ANwof = accumulation of the nutrient in the shoots without fertilizer; $\mathrm{QNa}=$ quantity of $\mathrm{N}$ applied. Utilization efficiency was calculated using the equation: $\mathrm{UE}=\mathrm{PE} \times \mathrm{RE}$, an index which considers physiological and recovery efficiencies. All efficiency calculations were 
performed according to Fageria et al. (2010).

To compare the mean of the two sowing systems (single and double rows), the data obtained were subjected to analysis of variance using the $F$ test $(p<0.05)$. In case of significant interaction between $\mathrm{N}$ doses and sowing system (single row and double row), the interaction was decomposed and polynomial regression analysis was applied to evaluate the effect of $\mathrm{N}$ doses. The analyses were performed in Agroestat software.

\section{Results and Discussion}

The $\mathrm{N}$ nutritional status of plants was affected by the factors sowing systems and/ or top-dressing $\mathrm{N}$ doses (Table 1). Chlorophyll index and leaf $\mathrm{N}$ content were influenced by both the sowing system and the top-dressing $\mathrm{N}$ doses applied in maize. However, there was no significant effect on these variables for the interaction between sowing system and $\mathrm{N}$ doses. The $\mathrm{N}$ content in the grain was influenced only by the $\mathrm{N}$ doses. Chlorophyll index and $\mathrm{N}$ contents in the diagnostic leaf and grain increased linearly with the increase in top-dressing $\mathrm{N}$ dose (Figure 2). The results for chlorophyll index and leaf $\mathrm{N}$ content showed the same response pattern as a function of $\mathrm{N}$ doses, corroborating that chlorophyll index is an important measure to evaluate the nutritional status of maize plants (Zhao et al., 2018).

Maize growth variables were influenced by sowing systems and/or top-dressing $\mathrm{N}$ doses (Table 2). Plant height and ear height were affected

Table 1. Chlorophyll index (CI) and nitrogen contents in leaf (N leaf) and grain ( $\mathrm{N}$ grain) as a function of the sowing system in single rows and double rows and top-dressing $\mathrm{N}$ doses.

\begin{tabular}{cccc}
\hline Treatments & CI & $\begin{array}{c}\mathrm{N} \text { leaf } \\
\mathrm{g} \mathrm{kg}^{-1}\end{array}$ & $\begin{array}{c}\mathrm{N} \text { grain } \\
\mathrm{g} \mathrm{kg}^{-1}\end{array}$ \\
\hline Sowing system (SS) & & & \\
Single rows & $66.71 \mathrm{~b}$ & $36.00 \mathrm{~b}$ & 18.07 \\
Double rows & $70.79 \mathrm{a}$ & $37.89 \mathrm{a}$ & 18.68 \\
F test & $17.72^{*}$ & $37.73^{* *}$ & $8.65 \mathrm{~ns}$ \\
\hline CV \% (SS) & 4.0 & 2.2 & 3.2 \\
\hline N doses (N) & & \\
F test & $203.85^{* *}$ & $41.69^{* *}$ & $28.91^{* *}$ \\
\hline CV \% (N) & 2.6 & 2.8 & 5.3 \\
\hline Interaction SS x N & & \\
F test & $1.14 \mathrm{~ns}$ & $1.84 \mathrm{~ns}$ & $0.11 \mathrm{~ns}$ \\
\hline
\end{tabular}

CV: coefficient of variation; ns: not significant; *Significant at 5\% probability level; **Significant at $1 \%$ probability level; Different lowercase letters in the column differ by Tukey test at $5 \%$ probability level. 

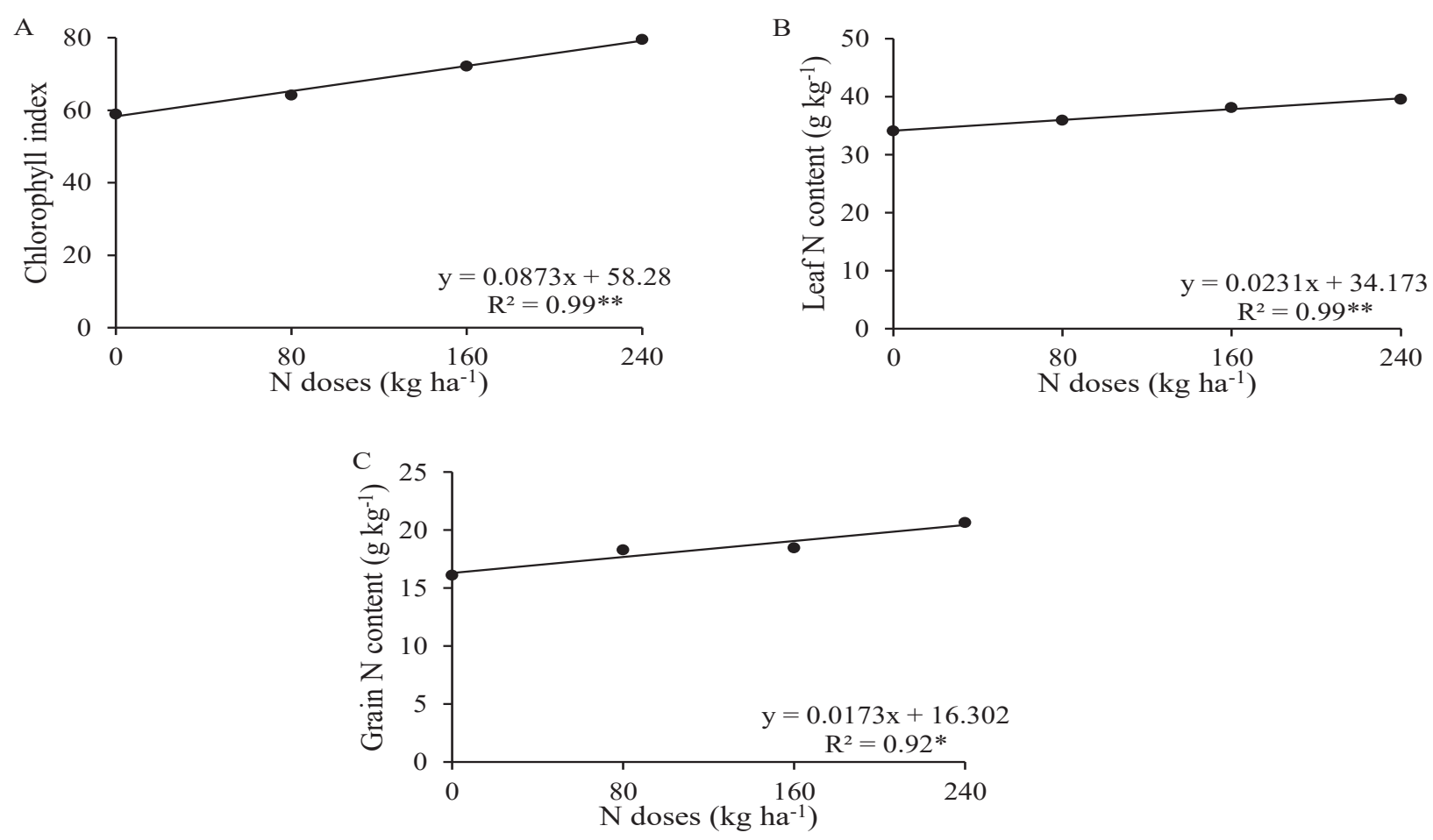

Figure 2. Chlorophyll index (A), leaf nitrogen content (B) and grain nitrogen content (C) in maize as a function of top-dressing $\mathrm{N}$ doses. ${ }^{*}$ Significant at $1 \%$ probability.

Table 2. Plant height $(\mathrm{PH})$, ear height $(\mathrm{EH})$ and stem diameter (SD) of maize as a function of the sowing system in single rows and double rows and top-dressing $\mathrm{N}$ doses.

\begin{tabular}{cccc}
\hline Treatments & PH & EH & SD \\
& $\mathrm{m}$ & $\mathrm{m}$ & $\mathrm{cm}$ \\
\hline Sowing system $(\mathrm{SS})$ & & $1.24 \mathrm{~b}$ & 1.63 \\
Single rows & $2.68 \mathrm{~b}$ & $1.26 \mathrm{a}$ & 1.70 \\
Double rows & $2.72 \mathrm{a}$ & $24.20^{*}$ & $3.82 \mathrm{~ns}$ \\
F test & $44.75^{* *}$ & 1.3 & 6.5 \\
\hline CV \% (SS) & 0.7 & & \\
\hline N doses (N) & & $88.90^{* *}$ & $23.25^{* *}$ \\
F test & $30.17^{* *}$ & 1.6 & 3.9 \\
\hline CV \% (N) & 1.0 & $0.34 \mathrm{~ns}$ & $2.64 \mathrm{~ns}$ \\
\hline Interaction SS x N & &
\end{tabular}

CV: coefficient of variation; ns: not significant; *Significant at $5 \%$ probability level; **Significant at $1 \%$ probability level; Different lowercase letters in the column differ by Tukey test at $5 \%$ probability level. 
by the factors sowing systems and top-dressing $\mathrm{N}$ doses. However, there was no significant effect on these variables for the interaction between sowing system and $\mathrm{N}$ doses. Stem diameter was affected only by the top-dressing $\mathrm{N}$ doses. The growth variables studied in the present experiment, as well as the variables of $\mathrm{N}$ nutritional status, increased linearly as a function of the increase in top-dressing N (Figure 3).

Fornasieri Filho (2007) highlights the importance of the maize stem to support the leaves and floral parts and to allocate to the sucrose reserve for translocation to the ears. The better $\mathrm{N}$ nutrition in maize promoted by the double- row sowing system led to greater growth and development of this cereal. For every $10 \mathrm{~kg}$ $\mathrm{ha}^{-1}$ of $\mathrm{N}$ applied as top-dressing, there were increments of $0.0051 \mathrm{~m}, 0.0065 \mathrm{~m}$ and $0.010 \mathrm{~cm}$ in plant height, ear height and stem diameter, respectively (Figure 3).

The variables related to the production components and grain yield showed different response patterns as a function of the sowing systems and top-dressing $\mathrm{N}$ doses (Table 3). Maize plant population was not affected by any of the factors, which can be attributed to good experimental control for this variable and the high accuracy at sowing.
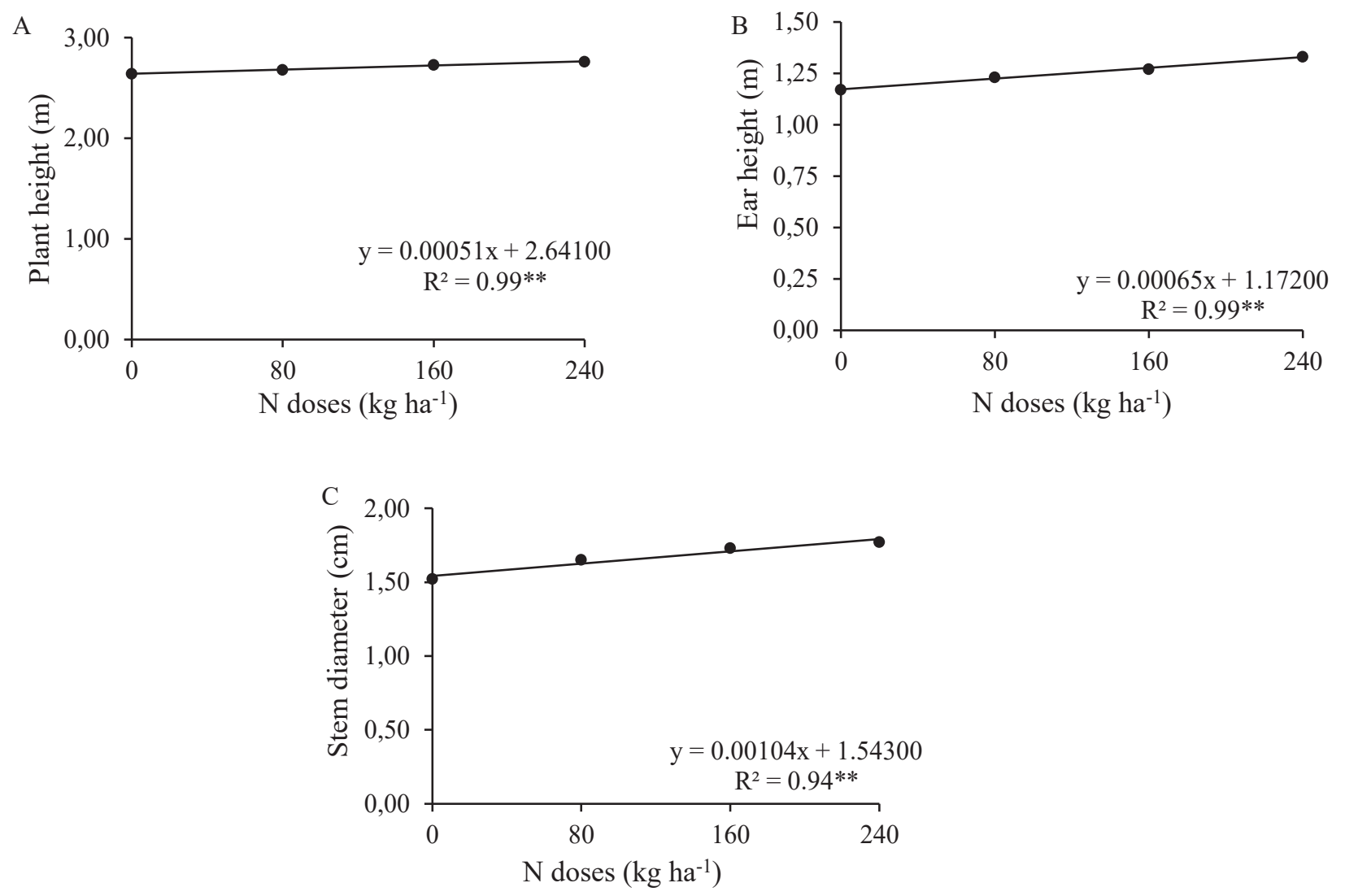

Figure 3. Plant height (A). ear height (B) and stem diameter (C) of maize as a function of top-dressing $\mathrm{N}$ doses. **Significant at $1 \%$ probability 
Table 3. Plant population (POP), number of rows per ear (NRE), number of grains per row (NGR), 1000 -grain weight $(1000 \mathrm{GW})$ and grain yield (GY) of maize as a function of the sowing system in single rows and double rows and top-dressing $\mathrm{N}$ doses.

\begin{tabular}{cccccc}
\hline Treatments & $\begin{array}{c}\text { POP } \\
\mathrm{pl} \mathrm{ha}^{-1}\end{array}$ & $\begin{array}{c}\text { NRE } \\
-\end{array}$ & $\begin{array}{c}\text { NGR } \\
-\end{array}$ & $\begin{array}{c}\text { 1000GW } \\
\mathrm{g}\end{array}$ & $\begin{array}{c}\mathrm{GY} \\
\mathrm{kg} \mathrm{ha}^{-1}\end{array}$ \\
\hline Sowing system (SS) & & & & & \\
Single rows & 57,625 & 17.16 & 36.56 & $337.17 \mathrm{a}$ & $10,268 \mathrm{a}$ \\
Double rows & 57,583 & 17.03 & 35.25 & $319.29 \mathrm{~b}$ & $9,740 \mathrm{~b}$ \\
F test & $0.02 \mathrm{~ns}$ & $0.86 \mathrm{~ns}$ & $6.47 \mathrm{~ns}$ & $58.38^{* *}$ & $24.48^{*}$ \\
\hline CV \% (SS) & 1.6 & 2.2 & 4.1 & 2.0 & 3.0 \\
\hline N doses (N) & & & & $36.21^{* *}$ & $115.20^{* *}$ \\
F test & $0.16 \mathrm{~ns}$ & $7.83^{* *}$ & $12.43^{* *}$ & 2.9 & 2.6 \\
\hline CV \% (N) & 2.0 & 3.7 & 3.5 & & $0.67 \mathrm{~ns}$ \\
\hline Interaction SS x N & & & & \\
F test & $0.20 \mathrm{~ns}$ & $0.94 \mathrm{~ns}$ & $0.37 \mathrm{~ns}$ & $4.09^{*}$ & \\
\hline
\end{tabular}

CV: coefficient of variation; ns: not significant; *Significant at $5 \%$ probability level; **Significant at $1 \%$ probability level; Different lowercase letters in the column differ by Tukey test at $5 \%$ probability level.

The numbers of rows per ear and grains per row were influenced only by the $\mathrm{N}$ doses, with no significant differences between the singlerow and double-row sowings systems. Bettio et al. (2017) also observed no difference in the number of rows per ear when comparing singlerow and double-row sowings systems. Balem (2013) observed for the double-row sowing system higher value of number of rows per ear when compared to the single-row sowing system, fact that was not verified in the present study. However, the 1000-grain weight was significantly affected by sowing systems, $\mathrm{N}$ doses and by the interaction between sowing systems and $\mathrm{N}$ doses. Based on the study of polynomial regressions, it can be verified that the number of rows per ear showed quadratic increment as a function of the $\mathrm{N}$ doses applied as top-dressing, with maximum value (17.6) observed at the $\mathrm{N}$ dose of $202 \mathrm{~kg} \mathrm{ha}^{-1}$ (Figure 4A).

The number of grains per row increased linearly as a function of $\mathrm{N}$ doses, with an increment of 0.15 grains per row for every $10 \mathrm{~kg}$ ha $^{-1}$ of $N$ (Figure 4B). For the single-row system, the 1000-grain weight increased quadratically as a function of $\mathrm{N}$ doses, with maximum value (351 g) obtained at the $\mathrm{N}$ dose of $193 \mathrm{~kg} \mathrm{ha}^{-1}$, while in the double-row system the increment was linear and equal to $2.20 \mathrm{~g}$ for every $10 \mathrm{~kg} \mathrm{ha}^{-1}$ of $\mathrm{N}$ applied (Figure 4C). In general, the singlerow system led to values, on average, 5.6\% higher than those of the double-row system for 

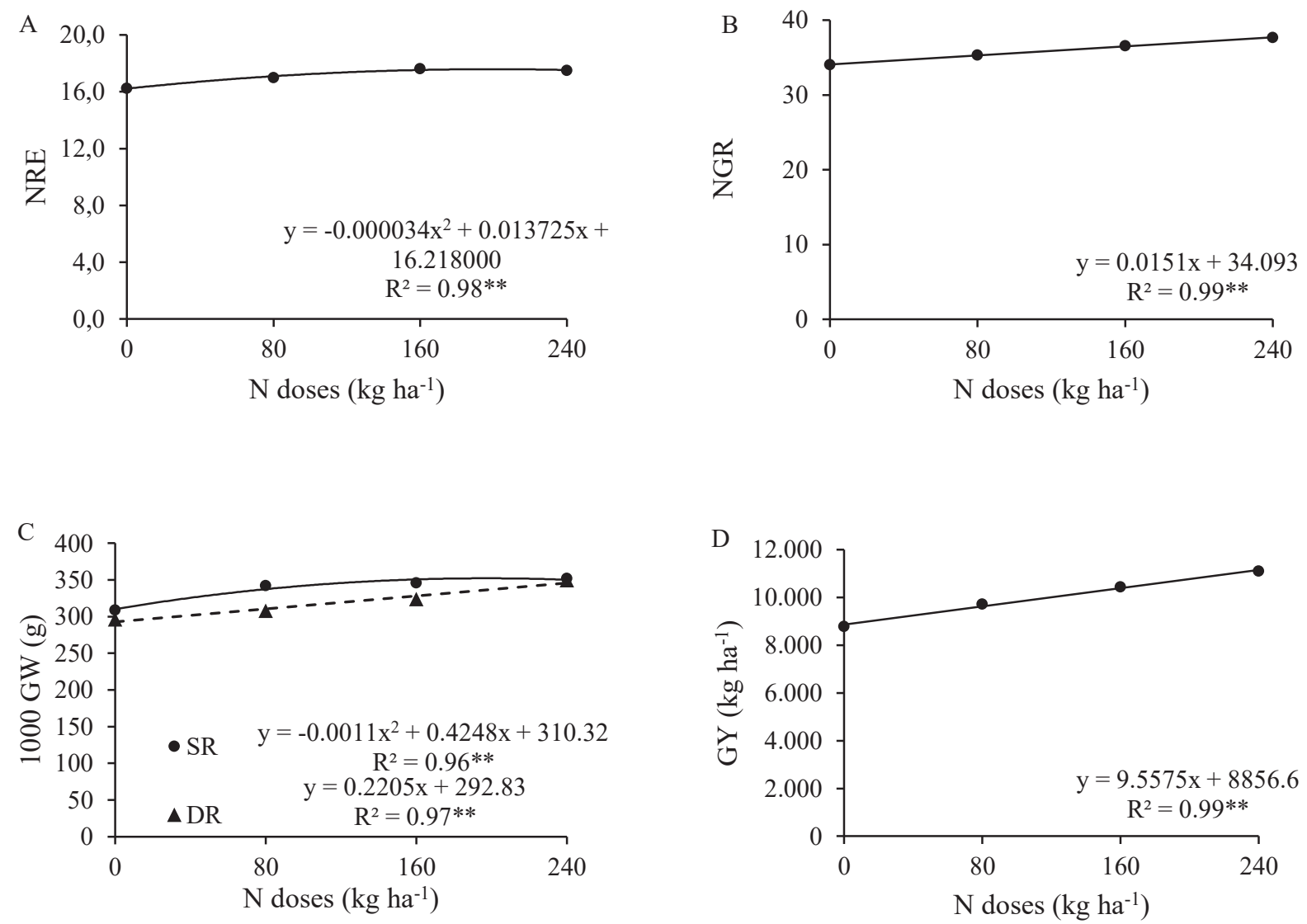

Figure 4. Number of rows per ear (NRE - A), number of grains per row (NGR - B), 1000-grain weight $(1000 \mathrm{GW}-\mathrm{C})$ and grain yield (GY - D) of maize as a function of top-dressing N doses. SR - single rows; DR - Double rows. **Significant at $1 \%$ probability

1000-grain weight (Table 3 ).

Maize grain yield was influenced by sowing systems and top-dressing $\mathrm{N}$ doses (Table 3 ). The single-row sowing system showed 5.4\% higher yield when compared to the double-row sowing system. A progressive linear increase was observed as a function of the increase in topdressing $\mathrm{N}$ doses in maize (Figure 4D). Although the double-row sowing system led to better nutrition and growth in height of maize plants, these results did not result in better agronomic performance of this cereal crop. This may be related to the maintenance of the same plant population in the sowing systems.

Super-early hybrids are responsive to high plant populations per hectare since, in general, they had smaller leaf area compared to genotypes with medium, normal or late cycle (Crusciol et al., 2013). The maize hybrid used in this experiment (AG9000PRO3) has erect leaf architecture, which may explain the lower utilization of solar energy in the plant population used $(60,000$ 
plants per hectare).

Jones (2010) verified, with a sowing of 76,000 plants per hectare, a $12.5 \%$ increase in maize grain yield when using the double-row sowing system compared to the single-row system. Balem (2013), in a study using an early maize hybrid with semi-erect leaf architecture, observed higher grain yield for the double-row system and progressive increments for grain yield with the increase in plant population up to close to 95,000 plants $\mathrm{ha}^{-1}$. It is worth noting that in the studies by Jones (2010) and Balem (2013), the spacing used in double-row systems was $0.19 \mathrm{~m} \times 0.57 \mathrm{~m}$ and $0.20 \mathrm{~m}$ x $0.70 \mathrm{~m}$, respectively, with mean spacing smaller than the one studied in the present study of $0.50 \mathrm{~m} \times 1.00 \mathrm{~m}$. Thus, the number of plants per meter in the present study is greater than in the two works cited, which may cause greater competition between maize plants in the planting row. Bettio et al. (2017) concluded that the double-row sowing system promoted a greater increment in maize grain yield, but the best result was obtained for the spatial arrangement of $0.20 \mathrm{~m} \times 0.70 \mathrm{~m}$ and population of 110,000 plants per hectare.

Area per plant is one of the key factors for the double-row sowing system, as there must be a spatial arrangement of plants that reduces competition for water and nutritional resources and optimizes grain yield (Carvalho et al., 2020a). However, in the present experiment, this factor was probably not relevant, since the experimental area was irrigated and had a history of high level of soil fertilization for the management of previous crops.
The differences between the sowing systems for grain yield and 1000-grain weight were $5.4 \%$ and $5.6 \%$, respectively. This shows the similarities in the variation of these variables, demonstrating that $1000 \mathrm{GW}$ was the component that explained the difference in yield between systems, besides being the only component that differed between sowing systems (Table 3). Although the irrigation depth in the experiment was the same for all treatments, the utilization of the water applied was different between the system. This occurs because the average spacing for the double-row sowing system was $0.75 \mathrm{~m}$, while for the singlerow system the spacing was $0.50 \mathrm{~m}$.

Consequently, for the plant population to be the same in the sowing systems, 4.5 seeds per meter were used in the double-row sowing system and 3.0 seeds per meter were used in the single-row sowing system. Carvalho et al. (2020b) evaluated the water use efficiency of maize under two row spacings $(0.50 \mathrm{~m}$ and 1.00 $\mathrm{m})$ and observed higher water use efficiency in maize cultivated with row spacing of $0.50 \mathrm{~m}$. This result confirms that larger spacings reduce the efficiency of water use by maize, directly affecting grain filling, so a greater amount of water is needed for the crop to obtain similar grain yield to that of smaller spacings.

The efficiency of $\mathrm{N}$ use (agronomic, physiological, agro-physiological, recovery and utilization) did not show significant differences between the single-row and double-row sowing systems (Figure 5). 


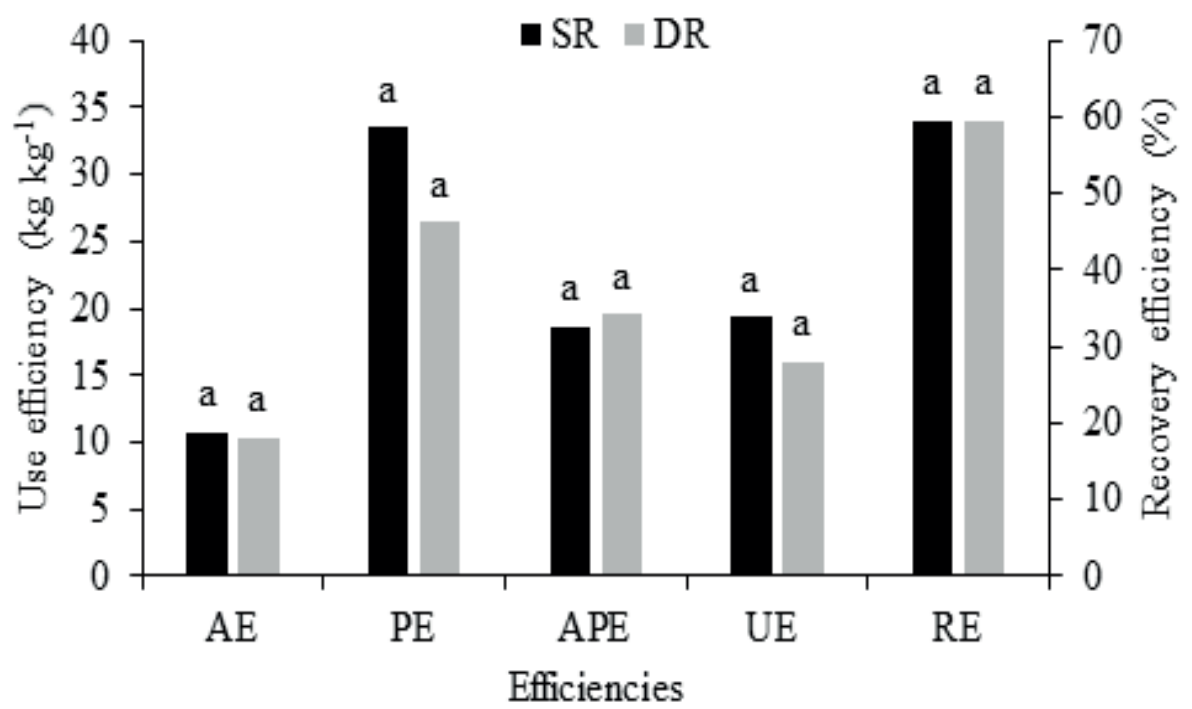

Figure 5. Agronomic efficiency (AE), physiological efficiency (PE), agro-physiological efficiency (APE), utilization efficiency (UE) and recovery efficiency (RE) of nitrogen applied as top-dressing in maize as a function of the sowing system in single rows (SR) and double rows (DR).

The same pattern of absence of differences for efficiencies was obtained between the topdressing $\mathrm{N}$ doses, except for physiological efficiency and utilization efficiency (Figure 6), which differed between among $\mathrm{N}$ doses. The use of efficiency indices enables a better understanding of how the nutrient is utilized and for which organs it is destined in plants (Leal et al., 2019).

The absence of significant differences between the sowing systems for efficiencies, especially for physiological and utilization efficiencies, indicates that the spatial arrangement used, with the super-early hybrid of erect leaf architecture, did not favor the increase in leaf area, making it difficult for plants in the doublerow system to convert their better $\mathrm{N}$ nutrition into compounds such as proteins and carbohydrates in leaves and grains. Physiological efficiency indicates the amount of shoot dry mass increased for each $\mathrm{kg}$ of $\mathrm{N}$ accumulated in the shoots, and the utilization efficiency represents the amount of shoot dry mass increased for each $\mathrm{kg}$ of $\mathrm{N}$ applied via fertilizers (Leal et al., 2019).

In general, the $\mathrm{N}$ use efficiency decreased with the increase in the dose applied as topdressing, as observed by Farinelli \& Lemos (2010). Carvalho et al. (2012) obtained a similar result when comparing 10 maize cultivars subjected to top-dressing fertilization with 40 and $160 \mathrm{~kg} \mathrm{ha}^{-1}$. The authors observed that there was no significant difference between the cultivars evaluated for the $\mathrm{N}$ content in the shoot dry mass. 


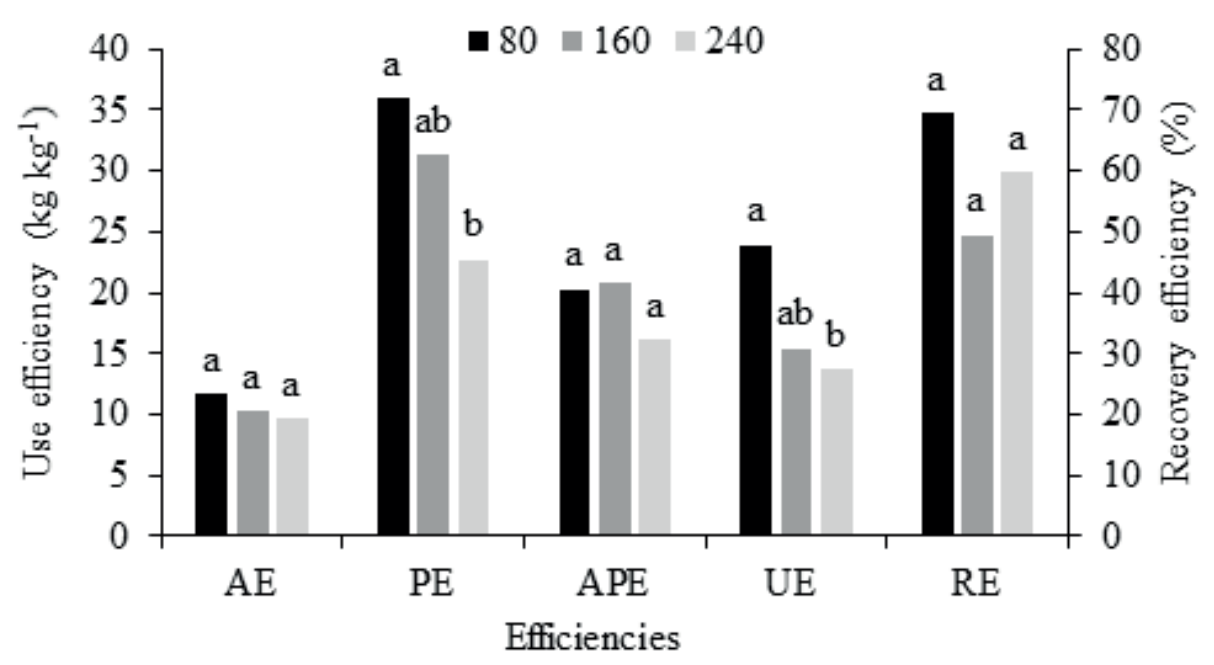

Figure 6. Agronomic efficiency (AE), physiological efficiency (PE), agro-physiological efficiency (APE), utilization efficiency (UE) and recovery efficiency (RE) of nitrogen doses applied as topdressing in winter maize.

\section{Conclusions}

The single-row sowing system leads to higher grain yield compared to maize grown in the double-row system.

Maize grain yield shows progressive linear increments with the increase in top-dressing $\mathrm{N}$ doses, reaching $11,500 \mathrm{~kg} \mathrm{ha}^{-1}$ of grains with the maximum studied dose of $240 \mathrm{~kg} \mathrm{ha}^{-1}$ of N.

Single-row and double-row maize sowing systems do not differ with respect to the use of top-dressing $\mathrm{N}$.

\section{References}

\begin{abstract}
ALLEN, R. G.; PEREIRA, L. S.; RAES, D.; SMITH, M. Crop evapotranspiration
\end{abstract}

- Guidelines for computing crop water requirements. Rome: FAO. 1998. 300 p. (FAO
Irrigation and Drainage Paper 56).

ALVARES, C. A.; STAPE, J. L.; SENTELHAS, P. C.; MORAES, G.; LEONARDO, J.; SPAROVEK, G. Köppen>s climate classification map for Brazil. Meteorologische Zeitschrift, Stuttgart, v. 22, n. 6 , p. 711-728, 2013. DOI: 10.1127/0941-2948/2013/0507.

BALEM, Z. Avaliação de espaçamento convencional e linhas gêmeas sob densidade populacional para cultura do milho. Dissertação (Mestrado em Agronomia) Universidade Tecnológica Federal do Paraná. Programa de Pós-Graduação em Agronomia. Pato Branco, PR. 2013.

BEN, L. H. B.; PEITER, M. X.; ROBAINA, A. D.; PARIZI, A. R. C.; SILVA, G. U. D. 
Influence of irrigation levels and plant density on "second-season" maize. Revista Caatinga, Mossoró, v. 29, n. 3, p. 665-676, 2016. DOI: 10.1590/1983-21252016v29n317rc.

BETTIO, C. S.; GANASCINI, D.; WUNSH, C. A.; RENOSTO, L.; MAGGI, M. F.; GURGACZ, F. Produtividade do milho (Zea mays L.) com diferentes arranjos populacionais em linhas simples e duplas. Acta Iguazu, Cascavel, v. 6, n. 3, p. 44-51, 2017.

CARVALHO, R. P.; VON PINHO, R. G.; DAVIDE, L. M. C. Eficiência de cultivares de milho na absorção e uso de nitrogênio em ambiente de casa de vegetação. Semina: Ciências Agrárias, Londrina, v. 33, n. 6, p. 2125 2136, 2012. DOI: $10.5433 / 1679-0359.2012 v 33 n$ $6 \mathrm{p} 2125$.

CARVALHO, M. W. L.; BASTOS, E. A.; CARDOSO, M. J.; ANDRADE JUNIOR, A. S.; SOUSA, C. A. F. Spatial arrangement of maize plants aiming to maximize grain yield in the hybrid BRS-3046. Australian Journal of Crop Science, Sidney, v. 14, n. 10, p. 1662-1669, 2020a.

CARVALHO, M. W. L.; BASTOS, E. A.; CARDOSO, M.J.,ANDRADE JÚNIOR,A. S.D.; SILVA, M. R. Productive performance of maize crop irrigated with and without water deficit in different plant arrangements. Revista Brasileira de Milho e Sorgo, Sete Lagoas, v.19, p. e1196, 2020b. DOI: 10.18512/rbms2020v19e1196

CRUSCIOL， C. A. C.; SORATTO, R. P.; BORGHI, E.; MATEUS, G. P. Benefits of integrating crops and tropical pastures as systems of production. Better Crops, Peachtree Corners, v. 94, n. 2, p. 14-16, 2010.

CRUSCIOL, C. A. C.; NASCENTE, A. S.; MATEUS., G. P.; BORGHI, E.; LELES, E. P.; SANTOS, N. D. Efect of intercropping on yields of corn with different relative maturities and palisadegrass. Agronomy Journal, Madison, v. 105 , n. 3 , p. $599-606,2013$. DOI: 10.2134/ agronj2012.0426.

FAGERIA, N. K.; MORAIS, O. P.; SANTOS, A. B. Nitrogen use efficiency in upland rice genotypes. Journal of Plant Nutrition, New York, v. 33, n. 11, p. 1696-1711, 2010. DOI: 10.1080/01904167.2010.496892.

FAO. FAOSTAT: crops data. Available in: $<$ http://www.fao.org/faostat/en/\#data/QC/>. Access in: 24 abr. 2020.

FARINELLI, R.; LEMOS, L. B. Produtividade e eficiência agronômica do milho em função da adubação nitrogenada e manejos do solo. Revista Brasileira de Milho e Sorgo, Sete Lagoas, v. 9, n. 2, p. 135-146, 2010. DOI: 10.18512/19806477/rbms.v9n2p135-146.

FORNASIERI FILHO, D. Manual da cultura 
do milho. Jaboticabal, SP: Funep, 2007. 576 p.

JONES, B. Effects of twin-row spacing on corn silage growth development and yield in the shenandoah valley. Blacksburg: Virginia Cooperative Extension, 2018. 9 p.

LEAL, F. T.; FILLA, V. A.; BETTIOL, J. V. T.; SANDRINI, F. O. T.; MINGOTTE, F. L. C.; LEMOS, L. B. Use efficiency and responsivity to nitrogen of common bean cultivars. Ciência e Agrotecnologia, Lavras, v. 43, p. e004919, 2019. DOI: 10.1590/1413-7054201943004919.

MALAVOLTA, A. E.; VITTI, G. C.; OLIVEIRA, S. A. Avaliação do estado nutricional das plantas: princípios e aplicações. 2. ed. Piracicaba: Potafos, 1997. 319 p.

NOVACEK, M. J.; MASON, S. C.; GALUSHA, T. D.; YASEEN, M. Twin rows minimally impact irrigated maize yield, morphology, and lodging. Agronomy Journal. Madison, v. 105, n. 1, p. 268-276, 2013. DOI: 10.2134/agronj2012.0301.

RAIJ, B. V.; CANTARELlA, H. Milho para grãos e silagens. In: RAIJ, B. V.; CANTARELLA, H.; QUAGIO, J. A.; FURLANI, A. M. C. Recomendações de adubação e calagem para 0 Estado de São Paulo. 2 ed. Campinas: Instituto Agronômico: Fundação IAC, 1996. p. 56-59. (Boletim Técnico, 100).

ROBLES, M.; CIAMPITTI, I. A.; VYN, T. J.
Responses of maize hybrids to twin-row spatial arrangement at multiple plant densities. Agronomy Journal, Madison, v. 104, n. 6, p. 1747-1756, 2012. DOI: 10.2134/agronj2012.0231.

SANTOS, H. G.; JACOMINE, P. K. T.; ANJOS, L. H. C.; OLIVEIRA, V. A.; LUMBRERAS, J. F.; COELHO, M. R.; CUNHA, T. J. F. Sistema brasileiro de classificação de solo. 3 ed. Brasilia, Embrapa, 2018. 390p.

SEMENTES AGROCERES. Descrição do híbrido de milho AG9000PRO3. Available in: $<$ http://www.sementesagroceres.com.br/pages/ Produto_AG_9000.aspx $>$. Access in: 18 nov. 2020.

XU, J.; CAI, H.; WANG, X.; MA, C.; LU, Y.; DING, Y.; WANG, X.; CHEN, H.; WANG, Y.; SADDIQUE, Q. Exploring optimal irrigation and nitrogen fertilization in a winter wheat-summer maize rotation system for improving crop yield and reducing water and nitrogen leaching. Agricultural Water Management, v. 228, 105904, 2020. DOI: 10.1016/j.agwat.2019.105904.

ZHAO, B.; ATA-UL-KARIM, S. T.; LIU, Z.; ZHANG, J.; XIAO, J.; LIU, Z.; QIN, A.; NING, D.; YANG, Q.; ZHANG, Y.; DUAN, A. Simple assessment of nitrogen nutrition index in summer maize by using chlorophyll meter readings. Frontiers in Plant Science, v. 9, n. 11, p. 1-13, 2018. DOI: $10.3389 /$ fpls.2018.00011. 